\title{
THE LOS ANGELES COAST AS A PUBLIC PLACE
}

\author{
RONALD A. DAVIDSON and J. NICHOLAS ENTRIKIN
}

\begin{abstract}
In the public-space discourse Los Angeles is usually portrayed as more "anti-city" than city. Its landscape is overrun by houses, "private-public" squares and plazas, theme parks, shopping malls, and so on and lacks inclusive public places. Yet this discourse has essentially disdained to contemplate a major public space that contradicts its general thesis: the Los Angeles coast. The coast is meaningful public place in two specific senses. First, it symbolizes Los Angeles as a whole and therefore provides a basis for regional public identity. Second, Angelinos themselves take the coast seriously as a public place, and they have striven to make it inclusive in practice. Keywords: beaches, California, coastal access, Los Angeles, public place.
\end{abstract}

$\mathcal{A}$

$\mathrm{n}$ article in the 25 August 2003 Los Angeles Times entitled "Malibu Civics Lesson" describes a confrontation on one of Southern California's most famous beaches. The specific incident took place on a stretch of the Malibu coastline known as "Broad Beach" (Figure 1), which sits in front of a line of beachfront homes noted for their celebrity owners. The incident involved a confrontation between a private security officer and a Malibu resident over access to a particular part of Broad Beach. The event eventually escalated to involve the Los Angeles County Sheriff's Department. Such confrontations are not unusual in this area in that it has been a site of frequent conflict between homeowners and the beach-going public over disputed terrain. What made this particular event newsworthy was the fact that the incident was instigated by sixty-four-year-old Malibu resident Sara Wan, a member and former chairperson of the California Coastal Commission. The commission, which is given the general charge of regulating the development of California's 1,100-mile-long coastline, takes as one of its responsibilities the guarding of public access to the beach. Wan intentionally placed a blanket in an area that signs indicated was private property, and her action had the desired result of provoking a reaction from the private security guard, who warned Wan that she was trespassing.

This incident would seem like one of many such minor conflicts that occur along this beach and others in Southern California, one that could have been relatively simply, yet hardly precisely, resolved by invoking the California public-access law. But California's law is more difficult to enforce than are those of many other states because it designates the high-tide line as the dividing line between public and private property. When Los Angeles County Sheriff's Department deputies arrived at the request of the security guard, they learned that even their training to apply this ambiguous territorial limit proved to be insufficient to counter Wan's claim. She explained, with appropriate documentation, that the situation at Broad Beach was

Dr. Davidson is a visiting assistant professor of geography at California State University, Northridge, California 91330. DR. ENTRIKIN is a professor of geography at the University of California, Los Angeles, California goog5.

The Geographical Review 95 (4): 578-593, October 2005 Copyright (C) 2006 by the American Geographical Society of New York 


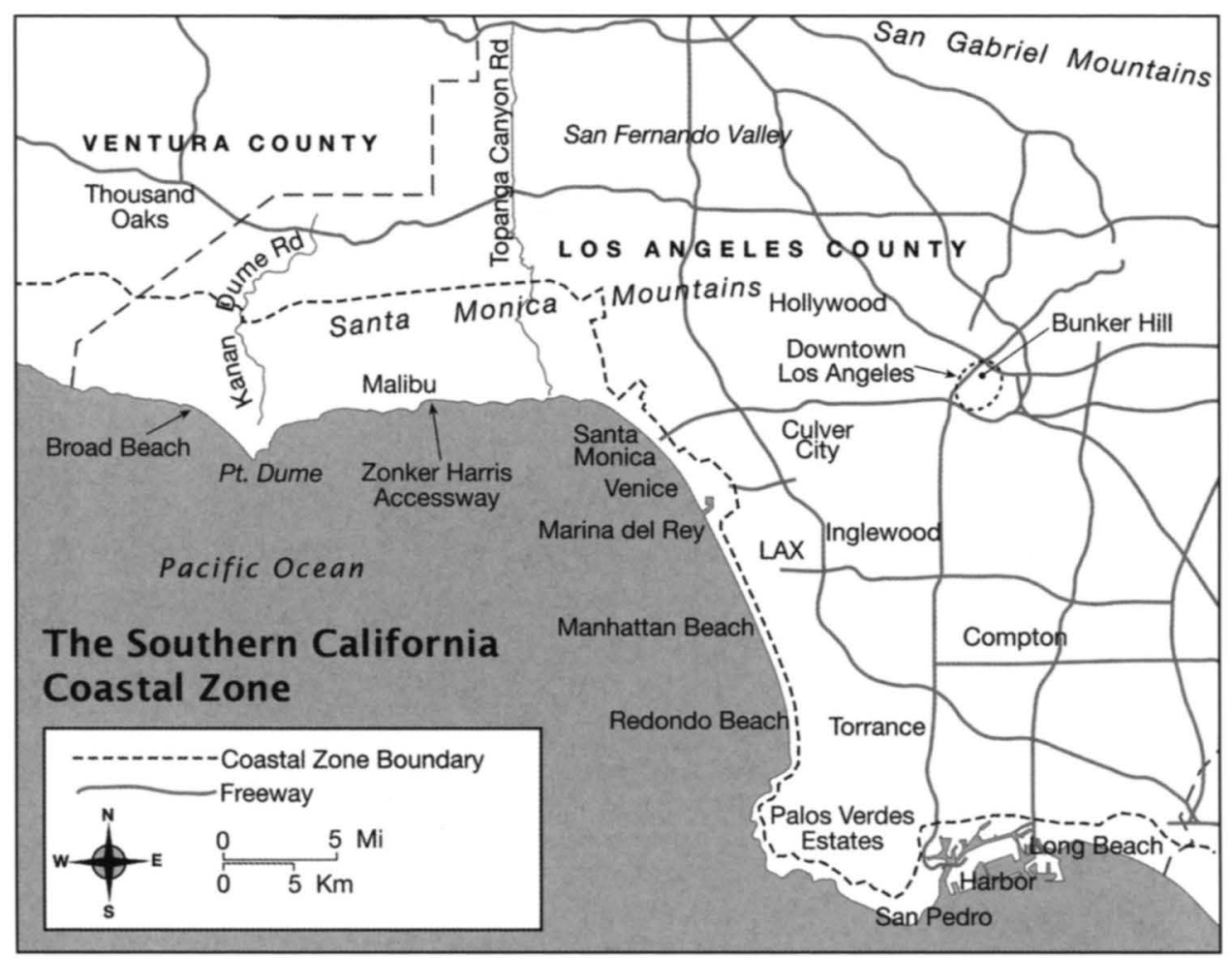

Fig. 1-The coastal zone of Southern California contains some of the most symbolic and inclusive public places in the region. (Cartography by Chase Langford, University of California, Los Angeles)

more complicated. She showed the officers that 43 of the 108 houses built along the sand had public easements tied to their property. Such easements allowed access on the inland side of the high-tide line from anywhere between 25 feet to the edge of the built property. Of course, the private-property warning signs do not indicate these deviations; the guards and deputies were apparently ignorant of them as well; and few beachgoers have easy access to the documents produced by a California Coastal commissioner.

Activists have expressed hope for more accurate signage and possibly maps, but it appears that little will be done. In fact, the whole episode seems to reinforce the image of Southern California, described several decades ago by the urban historian Sam Bass Warner as a region in which privatized places dominate and diminish public places (1972). ${ }^{1}$ Another interpretation, one that provides the central theme of this article, is that the classic model of urban public space that influences the assessment of impoverished public space of the Los Angeles metropolitan area overlooks the beaches specifically and the coastal area in general. These spaces, so often discounted as mere recreation areas, need to be examined as more complex places in which the battle of public and private takes form in this decentralized metropolitan region. 
The categorical distinction between public and private places is itself of less interest than is the shifting boundary between them. As Lynn Staeheli and Don Mitchell (2004) argue, the public and private realms are necessarily defined in relation to each other, and this relation changes, particularly in the fluid social relations of contemporary societies. The intuitive sense of public places as being eliminated by the steady expansion of the private sphere in modern life is only partially correct, in that it assumes a preexisting realm of the public that is being displaced. In fact, the struggle over bounding private and public spaces is a continual place-making process highlighting the negotiation over the rules that govern place. Often, as in this case, it is a contest over property and is characterized by conflict (Mitchell 2003; Blomley 2004).

A frequently neglected element of this view of place is the way in which it mirrors a similarly processual view of democracy and the public sphere (Entrikin 2002). One of the most enduring formulations of this view is found in the political theory of the American pragmatist philosopher John Dewey (1927, 15-16), who defined the public as consisting of "all those who are affected by the indirect consequences of transactions to such an extent that it is deemed necessary to have those consequences systematically cared for." Such a coming together offers a somewhat spontaneous form of collective action that may or may not lead to state action. The public, however, is independent of the state, and, as Bruno Latour (2003) argues in his laudatory review of the first French translation of Dewey's classic piece, must reinvent itself continually through new channels and modes of expression. To the extent that the indirect consequences that create publics involve reconsideration or reconstitution of the rules governing place, one may speak of the creation of public place. The coast may be seen in these terms as the site of such radically democratic collective actions. Sometimes these actions lead to state intervention, as in the constitution of the California Coastal Commission. More often they result in relatively small, collective actions, groups that come together to address and overcome exclusionary practices. Along Los Angeles' coast these skirmishes may range from battles among "local" and "outsider" surfers over access to particular beaches to larger-scale issues of the rights of beach access all along the coast (Perry 1995; Los Angeles Times 1996; 2002a; 2002b; New York Times 2002; Weiss 2002a, 2002b). What makes them particularly Deweyan in form is that they are waged occasionally through the agents of the state but more often through the formation of issue-specific, ephemeral coalitions and communal organizations.

Thus, when simmering conflict erupted in violence between "locals" and other surfers at several of the surfing beaches near the wealthy community of Palos Verdes Estates, the regional press and nongovernmental associations helped over several years to overcome previous inaction of governmental agencies in seeking a resolution. After the first publicized episode, public pressure forced city officials to declare publicly that their beaches were open to all (Perry 1995; Los Angeles Times 1996). Renewed conflict led to the involvement of the South Bay chapter of the Surfrider Foundation, whose charter includes the goal of "assuring public access to beaches 
and surf breaks." Toward this end, the foundation worked with the Palos Verdes Estates police in maintaining constant video surveillance of the contested beach. The video is linked both to the police and to the Surfrider Web site and serves the dual purpose of being a deterrent to further violence and a regional advertisement for local surfing conditions (Weiss 2002a). The chapter declared a "War on Localism," which involved, among other projects, organizing public events such as beach cleanups to assert symbolically the "opening" of the Palos Verdes beaches (Surfrider Foundation 2002).

Some geographers may view disputes over beach property and access as a light diversion from the more compelling contests over the public spaces of central-city cores or more centrally located urban parks (although leisure activities are certainly an important element of the latter; see Young 2004). What is overlooked is that this geographical standardization misses the many different types of public places and their varying significance in the full panoply of metropolitan regions. In a number of world cities, most notably in Los Angeles and Rio de Janeiro, the beach is not merely a recreation area. It is also an important geographical symbol and material landscape that both represents and manifests communal ideals of inclusiveness and belonging. To the residents of Rio, the common expression "Boa Praia!" ("Have a good beach!") is an affirmation of a way of life and a reflection of a spirit of equality at the beach that is strikingly at odds with the deeply fragmented social geography of Brazilian society (Roth-Gordon 2002, 156). For residents of both Los Angeles and Rio de Janeiro, cities widely viewed as deficient in terms of their urban public park system, the beach is a symbol of the public. This ideal remains strong even as the mapping of income levels in both cities makes the beaches appear as spatial extensions of the wealthiest residential areas. Such geographies give added significance to public demonstration in support of the inclusiveness of these unique urban edges.

\section{Deviant Los Angeles}

Los Angeles is famously a decentered city. Urban historians and geographers have called it a "fragmented metropolis" (Fogelson 1967), a "postmodern" city (Soja 1989), a "technoburbia" (Fishman 1987), and so on. Such terms have different theoretical and technical implications but all indicate Los Angeles' radical deviation from the classic industrial-pre-automobile-city model, in which concentric rings of homogeneous development emanate from a central business district. The observation that Los Angeles has an unusual physical form is of course not a new one: Even while the Chicago School theorists were developing their industrial-city model in the early twentieth century, many writers were adapting the title of Luigi Pirandello's 1921 avant-garde play Six Characters in Search of an Author and were calling Los Angeles "six suburbs in search of a city" (Krim 1992, 124; see also Hise, Dear, and Shockman 1996).

The perception of Los Angeles' unusual spatial form is paralleled by a critical and unflattering assessment of the city's social life. This assessment begins most potently in the realm of popular culture in the 1930 with the invention of series 
noir, Los Angeles' hard-boiled genre associated with such writers as Raymond Chandler, Horace McCoy, and James M. Cain. Chandler's antihero Philip Marlow roamed the perpetually nocturnal space of Los Angeles' spiraling suburbs seeking answers to questions that deepened and darkened at every turn. In traditional detective stories typified by those of Agatha Christie, the world is an ordered and upright place with one evildoer to be unmasked and apprehended (Tuan 1985). In noir the whole world is corrupt, and only the detective-hero works toward justice-although he, too, could be a shady character. The implied dialectic between deformed urban space and deviant social life has expanded beyond noir to appear in a range of contemporary writings on Los Angeles and cities likened to it. A genre characteristic that these nonfiction works share with their fictional counterparts is the criticism of existing power relations that subvert any possibility of a meaningful public realm. Thus Los Angeles is a "Reluctant Metropolis" (Fulton 1997), a "City of Quartz" (Davis 1990), with an "Ecology of Fear" (Davis 1998) and an agglomeration of "paranoid spaces" (Flusty 1994) and "fantasy spaces" (Crawford 1992). Such terms link place and social life to suggest that something is amiss in Los Angeles' form and content.

At one level, the form-content critique can be read as superficial, as drawing conclusions about content based on observations of form. "It has been tempting," wrote David Brain, "to assume that the city as urbs, as a dwelling place and an assemblage of material artifacts, reveals the fundamental character of the city as civitas, as a form of association, a moral order, or a political community" $(1997,239)$. As Brain indicates, the form-content critique of the public-space discourse involves the material form of the city and the content of the political life within it. Consider the case of ancient Athens, on whose city wall were inscribed the words "The man with no public business has no business" (Hauser 1998, 22) and in whose agora flourished a lively political culture (Sennett 1994). The link between form and content could not be clearer. This critique may intersect with an aesthetic reaction to Los Angeles as well- to the perceived "grotesqueness" of the city. According to Mark Dorrian (2000), the grotesque is characterized by the qualities of combination and disproportion. These two qualities fit the regnant, if not entirely accurate (Hise 1997), image of Los Angeles as a sprawling hybrid of settlement forms, an oxymoronic "suburban metropolis" that overwhelms the landscape and has no coherent structure or definite center. In contrast to the orderly radial pattern of the classic industrial city, Los Angeles is viewed as "amorphous" (Warner 1972, 136) and inchoate. The presumed connection between outer form and inner character is conditioned in the West by deeply rooted Platonic assumptions linking the ordered and the proper, the moral and the beautiful (Dorrian 2000). The perception seems to be that Los Angeles is misshapen and therefore monstrous.

The presumed link between form and content is one of three main reasons why Los Angeles emerged as the paradigmatic "anti-city" in what may be loosely called the "public-space discourse" over the last two decades. The second reason is the prevalence of themed "private-public" places that are regarded as spin-offs or ex- 
tensions of the regionally dominant--and, when evaluated as venues of public life, damned-fantasy spaces of Disneyland and Hollywood (Zukin 1991). The third is the sterility of the public areas on Bunker Hill, the core of the city's rebuilt downtown. Bunker Hill is the city's physical center and hence corresponds to the location in which the agoras, plazas, squares and other major public spaces are found in traditional European cities. The public areas on Bunker Hill compare poorly to these-often-idealized-analogous European city spaces (Loukaitou-Sideris and Banerjee 1998).

\section{Public Space on the Edge}

This negative view of Los Angeles is incomplete and perhaps inaccurate. Angelinos have not everywhere surrendered their civic consciousness to "commercial forces" (Fulton 1997, 343) or allowed their city to be deformed by bartering inclusive space for the security and illusions of a privatopia. To the contrary, Angelinos revealed an unsuspected streak of civic-mindedness by drawing a line around one highly symbolic public place and demanding that it remain open and inclusive; they have defended this place against privatization and development as well as its abandonment to the poor. This most inclusive of Los Angeles spaces is not downtown but, as may befit a decentered metropolis, at its edge. The coast of the Los Angeles metropolitan area, comprising the beaches, bluffs, and other shoreline landscapes, constitutes a symbolic and inclusive public place that has not received the attention it deserves in the public-space discourse. Angelinos have not abandoned the "inclusive urban commons" (Flusty 1994, 12) but have in part relocated it to the city's edge (Figure 1).

In what sense is the coast an important public place? At first blush, the coast may seem to be one of the least "important" spaces of Los Angeles-it is used mainly for recreational, "nonserious" activities, and it is on the city's edge. References to the coast are rarely made in the public-space discourse. Although the theme parks, shopping malls, parks and playgrounds, streets, and other urban places have been studied as public place, the 40 miles of public beaches and their nearby surroundings, running from Malibu to Palos Verdes, have been largely ignored. When the beaches are mentioned at all, the tone is usually dismissive, as if in spite of their massive size their unimportance was obvious. Lyn Hollen Lees, for example, takes an inventory of Los Angeles' public places and lists the beaches, city hall, college campuses, parks, squares, and streets. But Lees promptly subtracts the beaches-lumping them into the same category as malls and parking lots-because they lack, by his reckoning, wider civic functionality or utility in fostering community solidarity $(1994,450)$.

Perhaps the dismissive attitude toward the beach can be explained by the essayist Stephen Brook's comment that "the shore is regarded as a delightful adjunct to the city, not its defining feature" $(1992,191)$. Both the shore's delightfulness and its marginality are strikes against it. The delightful is "the good" stripped of metaphysical and "the aesthetic" stripped of moral significance; it is pleasurable and nothing more. Appropriately enough from this point of view, it was from an old word for coast or shore that the word "margin" derives, and "marginalia" means 
the unimportant, inessential (Stilgoe 1994, 10). In addition, much as Disneyland and Hollywood have lent force to the idea that privatized spaces throughout Los Angeles have mystifying powers, so too has the culture industry shellacked the beach with an extra layer of delightful unimportance. As Gidget and Baywatch and countless other beach-centered movies and television shows, novels, posters, and so on make clear, the beach is where superficial, tan-seeking crowds hang out doing basically nothing. Why be concerned about this place?

First, because the coast is a representative place. The coast and, more specifically, the beach represent the particular sort of good life that people have long associated with the city-it is "what life is all about in Los Angeles" (Banham 1971, 39). Second, the coast has been idealized as inclusive space. In a region that is overrun by "semi-public" spaces that filter out marginalized groups-with a large segment of the middle class's blessing or indifference-the coast presents a striking exception as a universally inclusive place. The coast is important public space, then, in a particular way. It represents the metropolitan community as a whole, and it is inclusive to all members of that community and to outsiders as well. These two facts, rather than the types of social interactions that take place on site, are what make the coast a meaningful public space. If this public space at the city's edge is taken seriously, as it should be, then one can argue that Los Angeles residents have not simply bartered public space for private space, as critics allege. Rather, they have shifted a portion of their public space to the city's margin, as perhaps befits a decentered metropolis, and they continue to defend its openness, as Wan's actions and the response to it by the press show. Her actions may be seen as an indication of a more widely shared belief expressed by California's former state librarian Kevin Starr, who describes the beach as the place that "Southern Californians had in common" and as the "first shared public space" $(2004,6)$.

\section{The Beach as Symbolic Space}

Now consider Brook's assertion that the shore is the "principal park" but not a "defining feature" of Los Angeles $(1992,191)$. We hold that the shore is vital, not accessory, to Los Angeles. Millions of Angelinos visit the beach on given weekends, and one study found that the majority of beach goers come from outside the local Westside areas (Edgerton 1979, 54-55). Sheer usage makes the beach important.

But the beach is equally important as a symbol of Los Angeles. The beach is precisely one of the city's "defining features," giving a new twist to Mike Davis's phrase "City of Quartz." The beach's significance is reflected by postcards and paintings of the city, guidebook covers, parking lots crammed with Angelinos' cars on weekends, Fourth of July fireworks celebrations, and culture products of every imaginable sort that evoke its style and presence. The beach is one of the most spectacularly popular and symbolic public places in Los Angeles. Reyner Banham called Los Angeles "the greatest city-on-the-shore in the world" $(1971,37)$, the hyphens implying that the city is not on but of the shore. Banham famously divided Los Angeles 
into four "ecologies," and the first he discussed was "surfurbia," the cities that lie along the old interurban electric car route at the shore and that "correspond most nearly to the surfside way of Angelino life" (p. 47). An insatiable market for Los Angeles' beach-themed products, from Baywatch to the Chevy Malibu to Beach Boys music, has popularized this image of the "Angelino way of life" internationally. LACity Tours includes three stops at coastal locations-Santa Monica Pier, Marina del Rey, and Venice Beach-making the beach a major part of its tour package (2006). Even the most basic package tours of Los Angeles offered by Japanese tourist companies include stops at Santa Monica beach (Moore 1985).

Thus when a gang war broke out on the coast between the (Latino) Venice-13 and the (African American) Shoreline Crips in the early 1990s, Starr worried about its impact on the international reputation of Los Angeles (1994). The problem was not simply the war's brutality. Motivated by competition for control of the lucrative crack-cocaine trade in the cluster of West Los Angeles communities stretching from Culver City to Santa Monica, seventeen people were killed and fifty injured in the war in less than a year (Ellingwood and Maher 1994). Yet these casualty figures - which rivaled those of the most brutal inner-city gang battles in the same period-do not explain the level of terror inflicted on the local communities. The capriciousness of the violence does. With pathological cruelty the gangs sought revenge against each other by targeting innocents of the rival gang's ethnicity as well as opposing gang members themselves (Ellingwood and Maher 1994). Many victims had no gang affiliations at all. Had such violence taken place in the "no-man's-land" of South Los Angeles, Starr argued, it would, sadly, not have mattered to the city as a whole. But when it happened at the coast - and especially in Venice, whose history of intertwined European cultural aspirations and funky beatnik idealism represents the "utopian impulses" of Los Angeles-it threatened to subvert the image of the entire city. In biblical tones Starr warned that "there is under way a struggle for the soul of Los Angeles itself-for the sealing off of the western shore in fear and terror would do violence to the very nature of Los Angeles" (1994).

Starr flirted with advocating a potentially disturbing double standard. Nevertheless, his premise seems correct: The shore represents the idealized qualities of Los Angeles just as South Los Angeles represents its flawed and tragic ones. To the shore attach the optimism, hope, and grandeur of the West and of nature, whereas the inner city is associated with racism, poverty, and crime. Perhaps both images are needed-the "fable" and the "counter-fable," to borrow Starr's terms for the rivaling and diametrically opposed images of California in the nineteenth century (1973, 120-126) - in any attempt to symbolically represent Los Angeles. Yet nobody chooses willingly to live in a dystopia; as the city's idyllic landscape the shore represents Los Angeles as an idea and an aspiration for all Angelinos. The shore is the "best" symbol of Los Angeles as a whole because it represents the particular sort of good life-materialistic, outdoor-oriented, in touch with nature--that has long attracted people to the region (Meinig 1979), even if reality has not turned out that way for everyone. Despite its location at the edge of the city, the shore is highly 
symbolic of the city. But meaningful public place needs to be more than symbolic. Crucially, it must also be inclusive.

\section{The Coast as Inclusive}

Here too the coast passes the test. The inclusiveness of the coast statewide has been fought for by Californians who remain alert to planning policies and actions by opportunistic developers and others who render portions of the coast exclusive. In California, the right to visit the shore is enshrined in the state constitution, which guarantees the public access to "all navigable waters" and requires that "the legislature shall enact such laws as will give the most liberal construction to this provision" (Constitution 1931, 813). This wording gives unusual force to the Public Trust Doctrine that protects citizens' access to the tidelands to varying degrees in all twentythree coastal states (Dean 1999, 125). In terms of physical access, this has meant that nowhere along California's 1,100-mile-long coast may private property extend seaward of the mean high-tide line. Much of the public shore in Los Angeles exceeds this minimum width. But does the legal provision for public access mean that the coast is in fact inclusive? Or, more important, do Angelinos desire the coast to be an inclusive public place? Are Wan's efforts described in the introduction simply idiosyncratic, another example of the quirkiness of Southern California personalist politics?

In the public-space discourse, the Angelino is typically portrayed as either grateful for or indifferent to the filtering of "others" from public space. This desire for exclusivity is explained as either a continuation of the centuries-old American impulse to move from the city to the garden (Lillard 1981) or, more typically, as an escape from the disturbing presence of "others" into private spheres of mental and material comfort (Avila 2004). This is most easily argued about the middle class behind its "spatial veil" (DeFilippis 1992), but, according to Steven Flusty (1994), even the marginalized groups desire spatial buffers from each other rather than copresence in public space. For this reason it is remarkable that Angelinos value the beach precisely as inclusive space. Angelinos have fought to spare the shore from usurpation by the wealthy just as they have abandonment to gangs. In 1972 they were leaders of the statewide grassroots movement to pass a citizens' initiative, Proposition 20, to "save the coast" from development practices that infringed on the public's constitutionally guaranteed right of access to the shore and from polluted and blighted coastal areas (Fischer 1985). The success of Proposition 20 led to the drafting of the Coastal Plan, which the legislature adopted as part of the Coastal Act of 1976. The act also created the California Coastal Commission, perhaps the most powerful state agency ever created by citizens' initiative, to ensure that development projects on the coast not impede public access or blight the shore. The Coastal Act has protected the coast from the sorts of exclusive spatial practices-such as construction of shopping centers and houses-that have run riot elsewhere in the Los Angeles Basin.

The coast therefore presents an exception to the pattern identified in the publicspace discourse. This discourse has rightly criticized middle-class Angelinos for 
abandoning many of their city's public places and practicing what William Fulton calls "Toon Town Urbanism" or "surrendering yourself to commercial forces" (1997, 343). It needs to be recognized, however, that Angelinos fought against these forces to protect the public access to the coast. Fifty-five percent of registered voters in Los Angeles cast their ballots in favor of Proposition 20 (Fischer 1985, 313-314), a significant number when one considers the pro-development, open-shop, anti-big-government philosophy that has reigned in the region since the late nineteenth century.

Moreover, Angelinos continue to protect the coast as a public place. The effort is required because the Coastal Act, though a shield against exclusive spatial practices along the shore, is not invincible. The commission has a checkered performance history in the face of political, legal, and economic challenges. Ellen Stern Harris, an activist who led the movement for coastal protection in the 1960 s and 1970 s and is known as the "Mother of the Coastal Act," later called the commission "a child that has gone astray" for granting too many development permits (quoted in Orsi 1996, 274). Peter Douglas, the commission's longtime executive director, inspired little confidence with his comment that "the coast, like any coveted place on earth, is never finally saved. Coasts always need saving and are always being saved" (1997, 326). The coast remains vulnerable to the sorts of territorial closures that afflict inland public places. Would-be developers of luxurious private homes, upscale restaurants, and so on are eager to build on coastal land; but gang activity, homelessness, and other signs of poverty have threatened to overwhelm sections of the coast-as in Venice-in ways that would discourage a middle-class presence. Resistance to either extreme is due not only to the work of the commission but also to the interventions of Angelinos who organized at the grassroots level to maintain the coast as an inclusive public place.

\section{Malibu Redux}

We move toward a conclusion by returning to Malibu and Sara Wan. Malibu was one of the most notorious examples of coastal mismanagement in the period leading up to Proposition 20. Because of exorbitant real estate prices, developers built houses shoulder to shoulder, leaving no room for pathways between them. The continuous wall of beachfront homes effectively limited coastal access to the homeowners themselves. Unfortunately, little has changed (Figure 2). During her period as chairwoman of the commission Wan told the New York Times, "I can't think of any place that's worse than Malibu" (2002). How did the commission plan to undo this development pattern and allow public access?

The commission had intended to open Malibu to the public by means of the exaction of offers to dedicate (OTDs). That is, for years the commission required as a condition for approval of new property development and redevelopment of existing property that the owner dedicate a certain amount of the property for either a horizontal (parallel to the shore) or vertical (perpendicular to the shore) public easement. The vertical easements would become pathways between houses to the shore. In 1987, however, the U.S. Supreme Court (Nollan v. California Coastal 


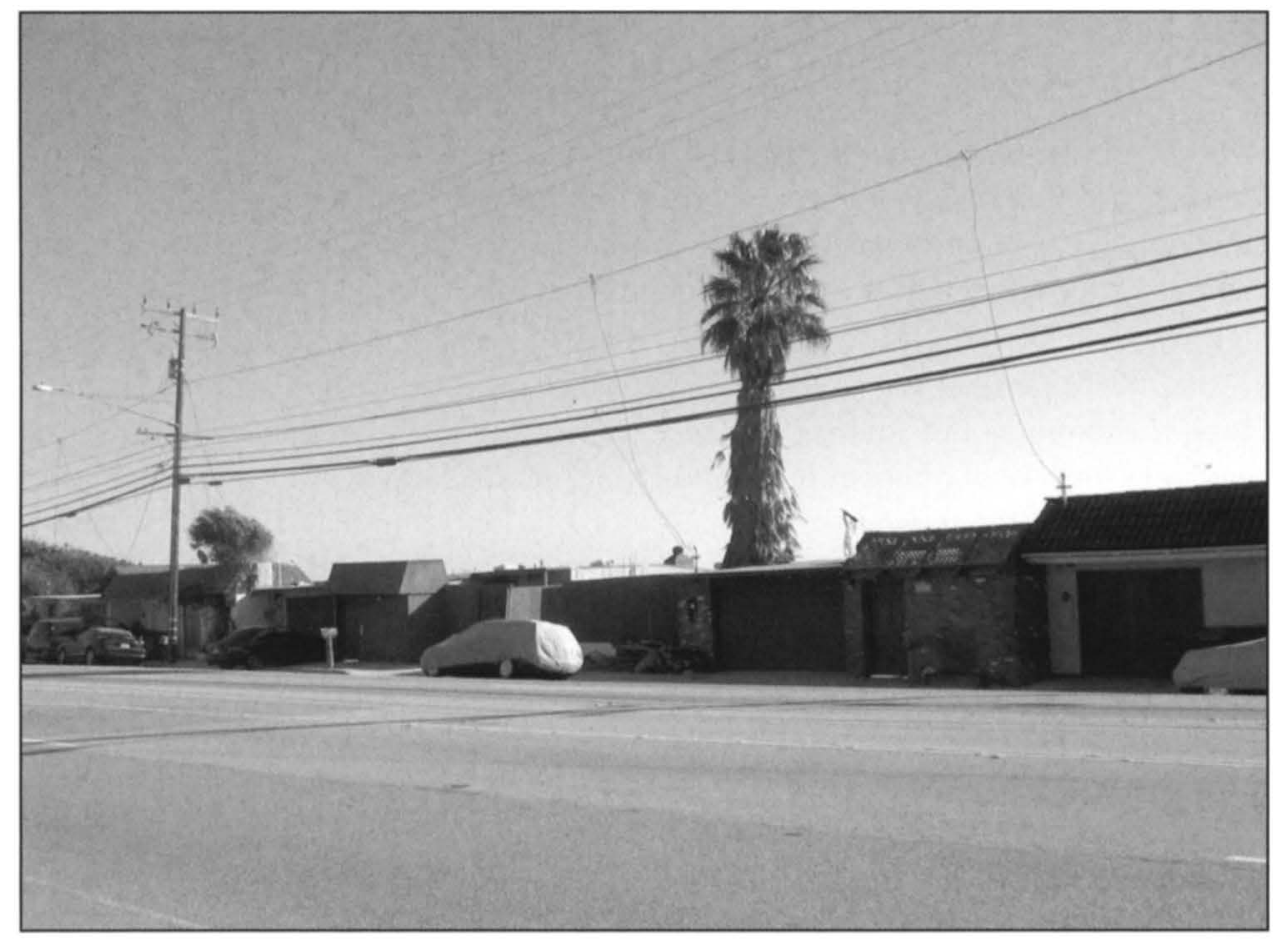

FIG. 2-Malibu houses, built shoulder to shoulder, block access to the beach in Southern California. (Photograph by Yoko Nasu, December 2005; reproduced courtesy of the photographer)

Commission) curtailed the commission's ability to exact oTDs, ruling that the commission had to determine more rigorously whether there was an "essential nexus" between the reduced access caused by a proposed development and the access to be provided by the public pathways (Bailey 1992, 962-964). Faced with an increasingly conservative Supreme Court that saw the commission's practice of granting conditional approvals as, in Justice Antonin Scalia's words, "an out-and-out plan of extortion" (quoted in Flick, Barnes, and Tufts 1995, 23), the commission halted the practice. Nevertheless, courts have upheld the validity of the approximately 1,300 OTDs made before 1987.

But the commission cannot by itself turn these paper easements into actual pathways to the beach. Under the Coastal Act public easements must be managed by local governments, or by components of the public such as nonprofit agencies or private citizens acting as land trusts (Buxton 1997). The act originally stipulated that if no such entity had stepped forward to manage an OTD within twentyone years after the deal was made, the offer would expire. By 2002, only about half of the state's oтDs, vertical and horizontal, had been turned into pathways. The majority of the rest of the OTDS, products of the land boom of the early 1980s, were set to expire over the next several years (New York Times 2002). The commission's sister agency, the Coastal Conservancy, subsequently agreed to assume liability for the oTDs (Lin 2006). This kept the window open for their possible 
future conversion into functional pathways, but as of February 2006 only 20 percent of the vertical ords had been turned into accessways. Los Angeles County operates eleven accessways, but long sections of the Malibu coast remain blocked by a continuous barricade of houses, tennis courts, gates, and chain-link fences. Along the 3-mile stretch from Malibu Pier to Big Rock, for example, there are numerous ords but only one actual pathway to the beach, the Zonker Harris Accessway (Figures 3-5).

A new nonprofit group, Access for All, has formed to secure greater access to Malibu beaches before the remaining otDs expire. The group has agreed to manage the walkway across movie mogul David Geffen's Malibu estate, an oTv Geffen made in 1983 in exchange for permission to remodel his Carbon Beach home. The group has drawn up a management plan as required by the conservancy, which handles the accessway program, and is negotiating with Geffen's lawyers (Weiss 2002b). The significance of the effort is larger than the creation of one more accessway, however: As a spate of emotional letters to the Los Angeles Times attests, it has inspired a renewed commitment to the ideal of the coast as inclusive space. Wrote one Angelino: "Excuse me for another rehash of the public's right to access the beach, but isn't this the law? And what on Earth makes these extremely wealthy folks believe they are above the law? Isn't this why we make laws? Let's all set a good example and obey the law" (Mervis 2002). In contrast to other areas in the region, the law requires that the coast remain fully accessible to all Angelinos.

Another letter writer suggested a radical zoning measure to maximize coastal access. By this measure "no one is allowed to build on the ocean side of the Pacific Coast Highway. All building occurs on the inland side only. Everyone gets to see and use the beach, and no one intrudes on anyone's privacy. Everybody wins" (Cohen 2002). In an editorial, the Los Angeles Times sided with those who desire an inclusive coast: "All homeowners want privacy, and fan-weary celebrities complain that they shouldn't have to put up with the occasional autograph seeker in a dripping bathing suit pestering them as they dine on their own decks. But when your home fronts on the public's beach, your choice is to put up with the public or move" (2002a).

\section{Inclusive Public Space and the Decentralized Metropolis}

Critics of Los Angeles have argued that the city lacks inclusive public places. Although this argument holds for much of the region, it ignores a major exception, the coast, which Angelinos have fought numerous battles to keep open and inclusive. The omission may be partly due to the bias of the public-space discourse to seek meaningful public places in the city center rather than at the city's edge. Yet, as a decentralized metropolis, Los Angeles' symbolically representative places may lie far from downtown. We have argued that the beach goes some distance toward representing the metropolis as a whole and that its inclusiveness has involved an active public. The effort began with the unified campaign to pass statewide legislation protecting coastal access but now often involves smaller-scale skirmishes-which 

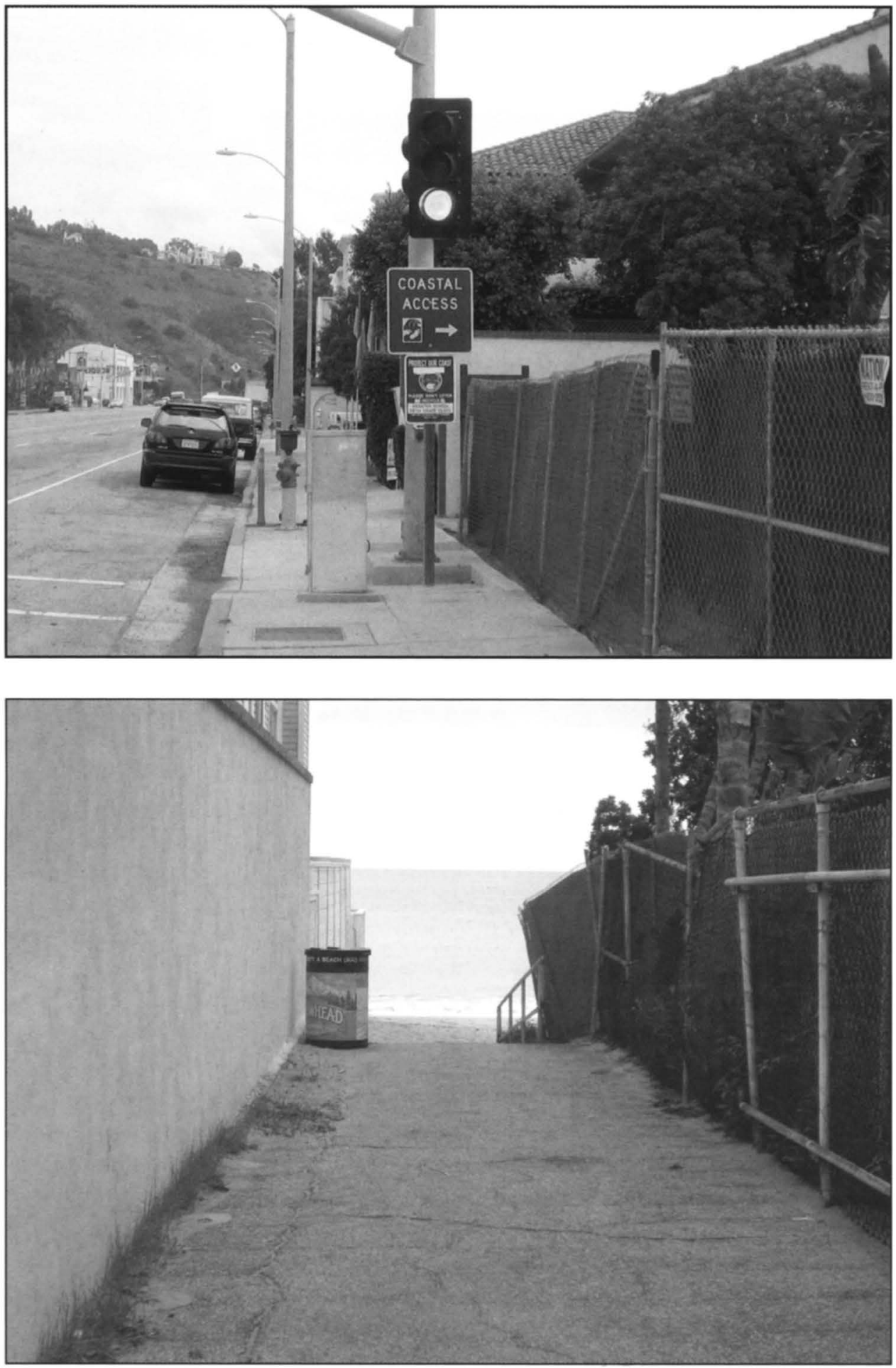


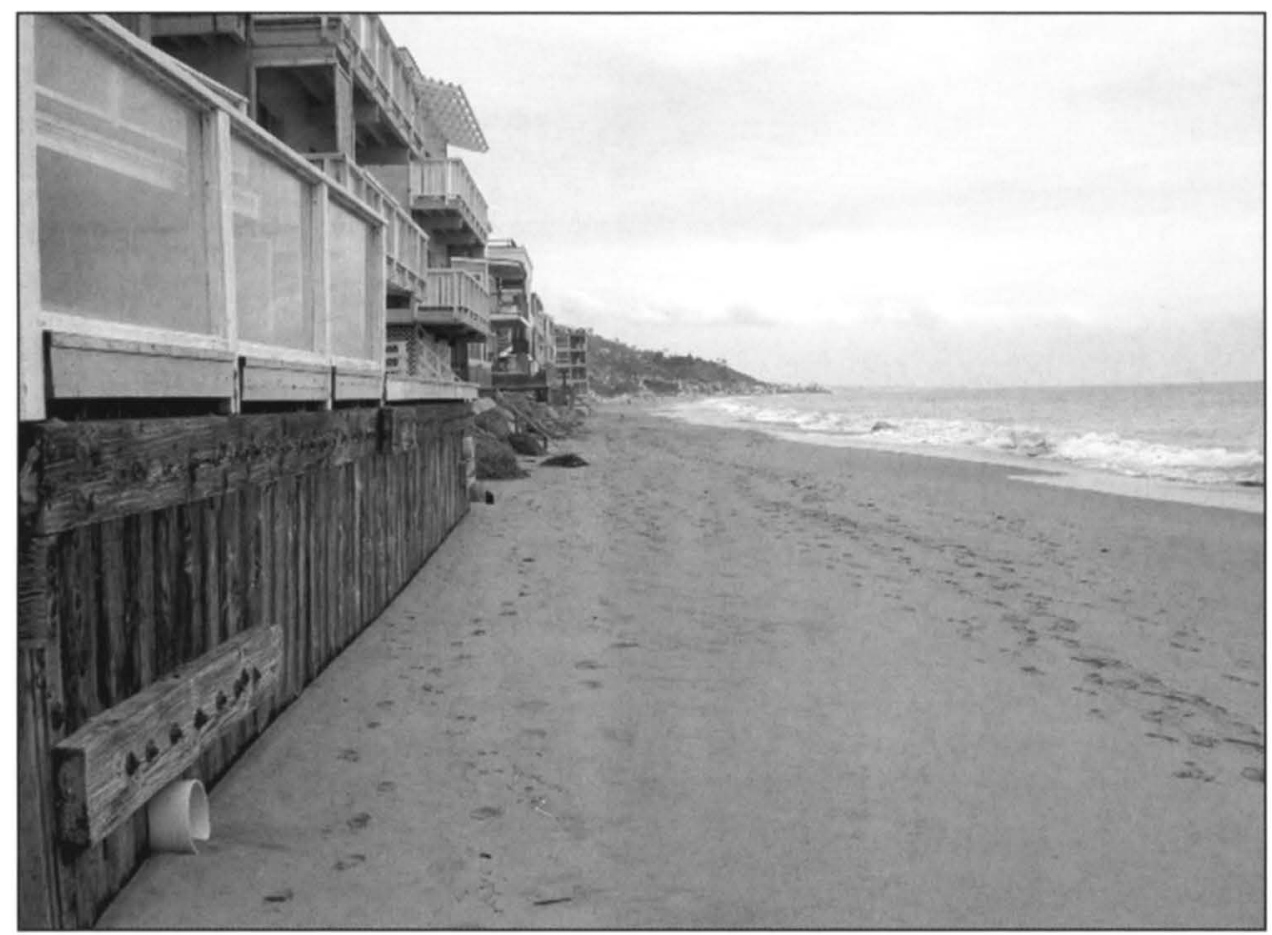

Fig. 3 (opposite page, top)-A "coastal access" sign at the entrance to the Zonker Harris Accessway to the Malibu beach. (Photograph by Ronald A. Davidson, December 2005)

Fig. 4 (opposite page, bottom)-The Zonker Harris Accessway cuts a pathway between buildings to the Malibu beach. (Photograph by Ronald A. Davidson, December 2005)

Fig. 5 (above)-The Malibu beach behind the Zonker Harris Accessway. (Photograph by Yoko Nasu, December 2005; reproduced courtesy of the photographer)

draw sustenance from the Coastal Act-against particular impairments to coastal access. These skirmishes take the form of a Deweyan public formation that becomes geographical to the extent that such collective action focuses on the rules of place, most notably rules that limit access or otherwise illegally or unfairly constrain the actions of members of the community.

The coast is not the sort of public place envisioned by many who write about public space as a metropolitan space in which diverse Others expand mutual horizons while negotiating their political and cultural differences. Furthermore, its location on the edge of the city rather than downtown defies traditional conceptions of the "sacred" centers of civil religion. It is a seemingly "profane" place of recreation and entertainment. Nonetheless, in some cities, but most notably in Los Angeles, the coast has come to symbolize the community and is consciously defended against anticommunal private development and idealized as an inclusive public place. It deserves to be taken more seriously in an expanded discussion of public place. 


\section{Note}

1. "Place" and "space" are used synonymously in this article to avoid unnecessary confusion. In the literature on the material manifestation of public and private spheres, one most often finds reference to the terms "private space" and "public space." In our view, the preferred term would be "public place" and "private place," which avoids confusion with other meanings of "space" and which emphasizes the constructed character of these bounded areas and their rules of access and inclusion.

\section{REFERENCES}

Avila, E. 2004. Popular Culture in the Age of White Flight: Fear and Fantasy in Suburban Los Angeles. Berkeley: University of California Press.

Bailey, S. 1992. Land Use Regulations and the Takings Clause: Are Courts Applying a Tougher Standard to Regulators after Nollan? Natural Resources Journal 32 (4): 959-975.

Banham, R. 1971. Los Angeles: The Architecture of Four Ecologies. New York: Harper \& Row.

Blomley, N. 2004. Unsettling the City: Urban Land and the Politics of Property. New York: Routledge.

Brain, D. 1997. From Public Housing to Private Communities: The Discipline of Design and the Materialization of the Public/Private Distinction in the Built Environment. In Public and Private in Thought and Practice: Perspectives on a Grand Dichotomy, edited by J. Weintraub and K. Kumar, 237-267. Chicago: University of Chicago Press.

Brook, S. 1992. L.A. Days, L.A. Nights. New York: St. Martin's Press.

Buxton, B. 1997. Happy Trails to You: How to Accept and Manage Offers to Dedicate Access Easements. San Francisco: California Coastal Commission and Coastal Conservancy.

Cohen, M. 2002. Letter to the Editor. Los Angeles Times, 10 January, \$2, 14.

Constitution. 1931. Constitution of the State of California. 6th ed. San Francisco: Bancroft-Whitney.

Crawford, M. 1992. The Fifth Ecology: Fantasy, the Automobile, and Los Angeles. In The Car and the City: The Automobile, the Built Environment, and Daily Urban Life, edited by M. Wachs and M. Crawford, 222-233. Ann Arbor: University of Michigan Press.

Davis, M. 1990. City of Quartz: Excavating the Future in Los Angeles. New York: Vintage Books.

- 1998. Ecology of Fear: Los Angeles and the Imagination of Disaster. New York: Henry Holt.

Dean, C. 1999. Against the Tide: The Battle for America's Beaches. New York: Columbia University Press.

DeFilippis, J. 1992. From a Public Re-Creation to Private Recreation: The Transformation of Public Space in South Street Seaport. Journal of Urban Affairs 19 (4): 405-417.

Dewey, J. 1927. The Public and Its Problems. Denver: Alan Swallow.

Dorrian, M. 2000. On the Monstrous and the Grotesque. Word and Image 16 (3): 310-317.

Douglas, P. M. 1997. Politic Politics and Other Realities of Coastal Management. In California and the World Ocean '97: Taking a Look at California's Ocean Resources: An Agenda for the Future, vol. 1, edited by O. T. Magoon, H. Converse, B. Baird, and M. Miller-Henson, 325-331. Reston, Va.: American Society of Civil Engineers.

Edgerton, R. B. 1979. Alone Together: Social Order on an Urban Beach. Berkeley: University of Califor nia Press.

Ellingwood, K., and A. Maher. 1994. Gunshots again Rake Venice. Los Angeles Times, 11 June, $\$$ B, 1, 5.

Entrikin, J. N. 2002. Perfectibility and Democratic Place-Making. In Progress: Geographical Essays, edited by R. D. Sack, 97-112. Baltimore, Md.: John Hopkins University Press.

Fischer, M. L. 1985. California's Coastal Program: Larger-Than-Local Interests Built into Local Plans. Journal of the American Planning Association 51 (3): 312-321.

Fishman, R. 1987. Bourgeois Utopias: The Rise and Fall of Suburbia. New York: Basic Books.

Flick, W. A., A. Barnes, and R. A. Tufts. 1995. Public Purpose and Private Property: The Evolution of Regulatory Taking. Journal of Forestry 93 (6): 21-26.

Flusty, S. 1994. Building Paranoia: The Proliferation of Interdictory Space and the Erosion of Spatial Justice. West Hollywood, Calif.: Los Angeles Forum for Architecture and Urban Design.

Fogelson, R. M. 1967. The Fragmented Metropolis: Los Angeles, 1850-1930. Berkeley: University of California Press.

Fulton, W. 1997. The Reluctant Metropolis: The Politics of Urban Growth in Los Angeles. Point Arena, Calif.: Solano Press Books.

Hauser, G. A. 1998. Civil Society and the Principle of the Public Sphere. Philosophy and Rhetoric 31 (1): $19-40$. 
Hise, G. 1997. Magnetic Los Angeles: Planning the Twentieth-Century Metropolis. Baltimore, Md.: Johns Hopkins University Press.

Hise, G., M. J. Dear, and H. E. Shockman. 1996. Rethinking Los Angeles. In Rethinking Los Angeles, edited by M. J. Dear, H. E. Shockman, and G. Hise, 1-14. Thousand Oaks, Calif.: Sage.

Krim, A. 1992. Los Angeles and the Anti-Tradition of the Suburban City. Journal of Historical Geography 18 (1): $121-138$.

LACity Tours. 2006. Los Angeles City Tour Highlights. [www.lacitytours.com/LACityTours.asp].

Latour, B. 2003. Pourquoi Marianne n'a plus de lait. Le Monde, 27 September, 1, 17.

Lees, L. H. 1994. Urban Public Space and Imagined Communities in the 1980s and 1990s. Journal of Urban History 20 (4): 443-465.

Lillard, R. G. 1981. Mountain Men and Women in the New West of Los Angeles. South Dakota Review $19(1 / 2): 29-40$.

Lin, S. 2006. Public Beach? Not so Fast. Los Angeles Times, 22 January, $\$ B, 1$.

Los Angeles Times. 1996. South Bay; Turf Wars between Surfers in Lunada Bay Is Settled. 4 December, $\S \mathrm{B}, 5$.

- 2002a. It's the People’s Coastline. 7 January, $\$ 2,10$.

- 2002b. The Waves Are for Everyone. 26 February, $\$ B, 12$.

- 2003. Malibu Civics Lesson. 25 August, $\$ B, 1$.

Loukaitou-Sideris, A., and T. Banerjee. 1998. Urban Design Downtown: Poetics and Politics of Form. Los Angeles: University of California Press.

Meinig, D. W. 1979. Symbolic Landscapes: Models of American Community. In The Interpretation of Ordinary Landscapes: Geographical Essays, edited by D. W. Meinig, 164-192. New York: Oxford University Press.

Mervis, R. 2002. Letter to the Editor. Los Angeles Times, 31 January, \$2, 18.

Mitchell, D. 2003. The Right to the City: Social Justice and the Fight for Public Space. New York: Guilford Press.

Moore, A. 1985. Rosanzerusu Is Los Angeles: An Anthropological Inquiry of Japanese Tourists. Annals of Tourism Research 12 (4): 619-643.

New York Times. 2002. California Fighting to Save Public's Access to Beaches. 7 January, $\$ A, 17,1$.

Orsi, J. 1996. Restoring the Common to the Goose: Citizen Activism and the Protection of the California Coastline, 1969-1982. Southern California Quarterly 78 (3): 257-284.

Perry, T. 1995. Turf Wars Spoil Sanctity of Southland Surf Beaches. Los Angeles Times, 8 May, §A: 1.

Roth-Gordon, J. 2002. Black Beach: How Slang Shapes Space in Rio de Janeiro. Ph.D. diss., Stanford University.

Sennett, R. 1994. Flesh and Stone: The Body and the City in Western Civilization. New York: W. W. Norton.

Soja, E. W. 1989. Postmodern Geographies: The Reassertion of Space in Critical Social Theory. New York: Verso.

Staeheli, L., and D. Mitchell. 2004. Spaces of Public and Private: Locating Politics. In Spaces of Democracy: Geographical Perspectives on Citizenship, Participation and Representation, edited by C. Barnett and M. Low, 147-160. London: Sage.

Starr, K. 1973. Americans and the California Dream, 1850-1915. New York: Oxford University Press. . 1994. Violence in Utopia: What the Venice Gang Killings Mean to LA. Los Angeles Times, 3 July, \$M, 1 .

- 2004. Coast of Dreams: Californians on the Edge, 1990-2003. New York: Alfred Knopf.

Stilgoe, J. R. 1994. Alongshore. New Haven, Conn.: Yale University Press.

Surfrider Foundation. 2002. Surfrider Foundation, South Bay Chapter, press release, 5 February. [http: //forums.surfline.com/archive/index.php/t-2259.html].

Tuan, Y.-F. 1985. The Landscapes of Sherlock Holmes. Journal of Geography 84 (2): 56-60.

Warner, S. B., Jr. 1972. The Urban Wilderness: A History of the American City. Los Angeles: University of California Press.

Weiss, K. 2002a. Too Many Surfers and Too Few Waves. Los Angeles Times, 24 February, $₫ B, 1$.

2002b. Activists Press Geffen for Beach Path. Los Angeles Times, 29 January, \$2, 1.

Young, T. 2004. Building San Francisco's Park, 1850-1930. Baltimore, Md.: Johns Hopkins University Press.

Zukin, S. 1991. Landscapes of Power: From Detroit to Disney World. Los Angeles: University of California Press. 